\title{
Silvio Serangeli, Il console Stendhal e la «petite ville» di Civitavecchia
}

\section{Michel Arrous}

\section{(2) OpenEdition}

\section{Journals}

Édition électronique

URL : http://journals.openedition.org/studifrancesi/5373

DOI : 10.4000/studifrancesi.5373

ISSN : 2427-5856

Éditeur

Rosenberg \& Sellier

\section{Édition imprimée}

Date de publication : 1 décembre 2016

Pagination : 542

ISSN : 0039-2944

\section{Référence électronique}

Michel Arrous, «Silvio Serangeli, Il console Stendhal e la «petite ville» di Civitavecchia », Studi Francesi [En ligne], 180 (LX | III) | 2016, mis en ligne le 01 janvier 2017, consulté le 18 septembre 2020. URL : http:// journals.openedition.org/studifrancesi/5373 ; DOI : https://doi.org/10.4000/studifrancesi.5373

Ce document a été généré automatiquement le 18 septembre 2020.

\section{(c) $(1) \&$}

Studi Francesi è distribuita con Licenza Creative Commons Attribuzione - Non commerciale - Non opere derivate 4.0 Internazionale. 


\title{
Silvio Serangeli, Il console Stendhale la «petite ville» di Civitavecchia
}

\author{
Michel Arrous
}

\section{RÉFÉRENCE}

SILVIO SERANGELI, Il console Stendhal e la «petite ville» di Civitavecchia, presentazione di Massimo Colesanti, Moncalieri, Edizioni del C.I.R.V.I, 2014, 366 pp.

1 Du fort volume enrichi d'un bel album iconographique qu'en 2010 il avait offert aux stendhaliens sur les réalités économiques et sociales du port des États pontificaux, fruit de recherches approfondies, Silvio Serangeli donne une version allégée où l'on trouvera par endroits d'utiles précisions, entre autres sur les divertissements archéologiques du consul - plus exaltants que la chasse aux lodole -, sur l'étruscomanie (voir les pages sur «Les tombeaux de Corneto», sur l'épouse de Lucien Bonaparte, pittoresque figure de l'entrepreneur en fouilles qui ne recueille que ce qui rapporte, sur Bucci et Manzi plus consciencieux et méthodiques), sur la signorina Luisa Mollica, alias mademoiselle «Mie de pain» dont Stendhal aimait les vocalises qu'il écoutait de son appartement du Palazzo Palomba. Défilent aussi le gonfalonier Paolo Vidau et sa fille, Toto, Lysimaque «il doppio»-, Mme «Os», bref le petit monde du consul qui, un beau jour de 1840, déclara préférer à tout autre le séjour de Civitavecchia (mais oui!) ou de Rome (tertium non datur). 